\title{
THE PROTECTIVE EFFECT OF PALIASA (Kleinhovia hospita L.) LEAF EXTRACT AGAINST ELEVATED TOTAL BILIRUBIN SERUM INDUCED BY TOXIC DOSE OF ANTITUBERCULOSIS IN RATS
}

\author{
Yulia Yusrini Djabir ${ }^{1}$,Imelda Dhea Meylin ${ }^{1}$, Rosany Tayeb ${ }^{2}$ \\ ${ }^{1}$ Clinical Pharmacy Laboratory, Faculty of Pharmacy, Hasanuddin University, Makassar, Indonesia \\ ${ }^{2}$ Pharmacognosy Laboratory, Faculty of Pharmacy, Hasanuddin University, Makassar, Indonesia \\ Corresponding author: \\ Yulia Yusrini Djabir \\ Clinical Pharmacy Laboratory, Faculty of Pharmacy, Hasanuddin University, Makassar, Indonesia \\ Email: yulia.yusrini@unhas.ac.id
}

\section{Article Info:}

Received: 10 May 2019

Revised: 12 Sep 2019

Accepted: 07 Oct 2019

Available online: 21 Oct 2019

Keywords: Antituberculosis, Paliasa leaf extract, total bilirubin serum

DOI: $10.20956 / n m s j . v 4 i 2.6474$

\begin{abstract}
Introduction: Liver dysfunction is implicated with the use of Antituberculosis (AT) leading to low compliance of TB patients to AT regimen. One of biomarker that is important to measure liver dysfunction is total bilirubin serum. Paliasa leaves have been emiprically used to improve liver function in South Sulawesi. This study aimed to determine the effect of ethanolic extract of Paliasa leaves on total bilirubin serum in rats.

Method: Twenty rats were devided into five groups: Group I served as the healthy control was only given $\mathrm{NaCMC}$ suspension, group II was treated with $178 \mathrm{mg} / 200 \mathrm{~g}$ of AT suspension, while group III, group IV and group V were given Paliasa extract $125 \mathrm{mg} / \mathrm{kgBB}, 250 \mathrm{mg} / \mathrm{kgBB}$ and $500 \mathrm{mg} / \mathrm{kgBB}$, respectively, 4 hours prior to AT administration. Treatments were performed once a day for 28 days. Blood sampling was carried out 24 hours following the last treatment. The total bilirubin levels were measured using Humalyzer 3500. Result: The results showed that the administrations of AT suspension for 28 days significantly increased rat total bilirubin levels. Paliasa leaf extract in all given dose was able to reduce the total bilirubin levels of rats compared to the group treated with AT only. However, statistical significance was only reached by the groups that were treated with Paliasa extract $500 \mathrm{mg} / \mathrm{kg}$.

Conclusion: Therefore, it is concluded that Paliasa extract at a dose of $500 \mathrm{mg} / \mathrm{kg}$ has protective effect against AT-induced elevation of total bilirubin serum in rats.
\end{abstract}

\section{INTRODUCTION}

Liver is the main metabolic organ of the body, which has complex functions in regulating the metabolism of nutrition, drugs or toxic compounds. As most drugs are metabolized in the liver, it becomes vulnerable to drug-induced liver injury, especially when the drugs produce toxic metabolites. ${ }^{1}$ The presence of liver injury or

damage is mainly detected by the elevation of liver enzymes in the serum, including alanine transaminase (ALT) and aspartate transaminase
(AST). In addition, serious malfunction of the liver can manifest in hyperbilirubemia due to the dysfunctional uptake, conjugation and excretion of bilirubin. ${ }^{2}$ If the concentration of bilirubin serum significantly elevates, it diffuses to the surrounding tissues leading to yellowish appearance of the skin and mucous membranes, commonly called as jaundice. ${ }^{3}$

The first line of antituberculosis regimen composes of Isoniazid (INH), Rifampicin (RIF), Pyrazinamid (PZA) and Ethambutol (EMB). 
Three of the four drugs (INH, RIF and PZA) are known to possess capability to harm liver function $^{4}$. As a result, high incidence of hepatotoxicity is found among tuberculosis patients treated with AT drugs around the world ${ }^{5-}$ ${ }^{7}$, affecting children and adult patients. ${ }^{8}$

Paliasa (Kleinhovia hospita L.) is a native plant from South Sulawesi that has been used traditionally to treat jaundice and hepatitis. ${ }^{9}$ Four cycloartane triterpenoid alkaloids have been isolated from Kleinhovia Hospita, i.e Kleinhospitines A, B, C and D, and these compounds have been shown to be protective against $\mathrm{H}_{2} \mathrm{O}_{2}$ radical induced damage in hepatocyte cell culture. ${ }^{10}$ In the previous study, Paliasa leaf extract with the dose of $250 \mathrm{mg} / \mathrm{kg}$ and $500 \mathrm{mg} / \mathrm{kgBB}$ were found to have the ability to reduce liver cell damage caused by carbon tetrachloride $\left(\mathrm{CCI}_{4}\right) .{ }^{11}$ More currently data on paliasa leaf extract also showed a superior protection against doxorubicine-induced hepatotoxicity with a dose of 250 and 500 $\mathrm{mg} / \mathrm{kg} .{ }^{12}$ However, there is still limited data exploring the capacity of Paliasa leaf extract on preventing hyperbilirubinemia, especially those induced by AT drugs. Therefore, the aim of this study is to determine the effect of Paliasa leaf extract on serum total bilirubin in rats treated with toxic dose of AT drugs.

\section{METHODS}

\section{Animal preparation}

Twenty male rats weighed 150-200 g were used in the study. The animals were fed with standard pellets and drink ad libitum. The animal care protocols were carried out based on institution animal standard of care. Rats were acclimatized for 14 days prior to treatment.

\section{Drug preparation}

Antituberculosis was purchased in fixed dose combination (Rifastar $($ ) ) in a local pharmacy. The tablets were pulverized and suspended in $\mathrm{NaCMC}$ $1 \%$ to facilitate oral gauge in rats. The AT suspension was made with $8.9 \mathrm{~g}$ of AT in $100 \mathrm{ml}$ suspension $(8.9 \%)$. The preparation of suspension was done on daily basis.

\section{Extract Preparation}

Paliasa (Kleinhovia hospita L.) leaves were obtained in Makassar. The samples were washed using tap water and dried in an oven $\left(40^{\circ} \mathrm{C}\right)$ before macerated in $70 \%$ ethanol (sample: ethanol =
1:10) for 24 hours followed by re-maceration for another 24 hours. The extract obtained was evaporated using a rotary evaporator (Heidolp $\left.{ }^{\circledR}\right)$ to form a thick extract. The extract was kept in a desiccator at room temperature to prevent it from excessive humidity. Immediately prior to treatment, the extract was prepared in $1 \% \mathrm{NaCMC}$ suspension.

\section{Experimental protocols}

Animals $(n=20)$ were assigned in 1 of 5 groups. Group I served as healthy control group was only given $1 \% \mathrm{NaCMC}$ suspension. Group II was treated with $178 \mathrm{mg} / \mathrm{kg}$ of AT drug suspension. Group 3 was treated with Paliasa leaf extract 125 $\mathrm{mg} / \mathrm{kg}$ prior to AT drug administration. Group 4 was treated with Paliasa leaf extract $250 \mathrm{mg} / \mathrm{kg}$ prior to AT drug administration. Group 5 was treated with Paliasa leaf extract $500 \mathrm{mg} / \mathrm{kg}$ prior to AT drug administration. All treatments were carried out for 28 days. Blood samples were withdrawn 24 hours following the last treatment. In addition, blood samples were randomly taken from nine healthy rats prior to treatment to measure baseline bilirubin level. The total bilirubin serum was measured using Humalyzer 3500 with Total Bilirubin Reagent $\mathbb{R}$ and T-Nitrite Reagent (Human $\left.{ }^{\circledR}\right)$.

\section{Statistical analysis}

Data is presented in mean \pm SD. Statistical analysis was performed using SPSS 24. The distribution of data was determined using Kolmogorov Smirnov analysis. Data then analyzed with One-way ANOVA. The significant difference between treatment groups was analyzed using post hoc Bonferonni test. Statistical significance is achieved if $\mathrm{p}<0.05$.

\section{RESULTS}

\section{Baseline serum total bilirubin}

In this study, the level of serum total bilirubin was measured using Humalyzer 3500. For healthy wistar rats, it is found that serum total bilirubin ranged from $0.090-0.205 \mathrm{mg} / \mathrm{dl}$ with the average of $0.613 \pm 0.045$ (Table 1 ). 
Table 1 . Serum total bilirubin in healthy rats measured using Humalyzer 3500

\begin{tabular}{ccccc}
\hline Rat & $\begin{array}{c}\text { Total } \\
\text { bilirubin } \\
\text { serum } \\
\text { (mg/d) }\end{array}$ & $\begin{array}{c}\text { Range } \\
(\mathbf{m g} / \mathbf{d l})\end{array}$ & $\begin{array}{c}\text { Mean } \\
(\mathbf{m g} / \mathbf{d l})\end{array}$ & $\begin{array}{c}\text { Standard } \\
\text { Deviation }\end{array}$ \\
\hline 1 & 0.237 & & & \\
2 & 0.090 & & & \\
3 & 0.198 & & & \\
4 & 0.130 & & & \\
5 & 0.157 & $0.090-$ & 0.163 & 0.045 \\
6 & 0.205 & 0.205 & & \\
7 & 0.170 & & & \\
8 & 0.159 & & & \\
9 & 0.125 & & & \\
\hline
\end{tabular}

\section{Serum total bilirubin after treatments}

Following 28 days of treatments, it is shown that rats that were only given NaCMC (healthy controls) had total bilirubin level within the baseline range (Figure 1). Meanwhile, rats that were treated with AT $178 \mathrm{mg} / \mathrm{kg}$ daily had significantly increased total bilirubin level. The mean level of total bilirubin in AT group was more than three times of those in NaCMC group. Administration of Paliasa leaf extract 125 and 250 $\mathrm{mg} / \mathrm{kg}$ was shown to reduce total bilirubin level in AT-treated rats. However, the reduction of total bilirubin levels in those groups did not reach statistical difference compared to AT group. In contrast, the administration of higher dose $(500$ $\mathrm{mg} / \mathrm{kg}$ ) seemed to improve the total bilirubin level significantly. Indeed, the level of total bilirubin in rats treated with $500 \mathrm{mg} / \mathrm{kg}$ extract ranged between $0.131-0.172 \mathrm{mg} / \mathrm{dl}$, which still falls in the baseline range (see table 1).

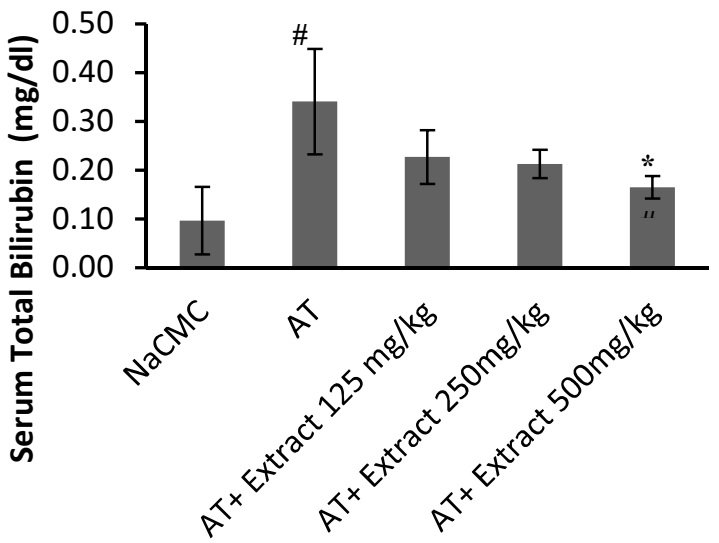

Figure 1. Serum total bilirubin in rats following 28 days of treatments.

${ }^{\#} \mathrm{p}<0.05$ compared to $\mathrm{NaCMC}$ group. ${ }^{*} \mathrm{p}<0.05$ compared to AT group

\section{DISCUSSION}

Bilirubin is a product of heme degradation during red blood cell decomposition. The unconjugated bilirubin is carried by albumin to the liver to undergo conjugation with the enzyme glucuronosyl transferase. The conjugation process led to formation of water-soluble bilirubin, thus, it is easier to be excreted. ${ }^{13}$ Serum total bilirubin is the sum of conjugated and unconjugated bilirubin in the serum. From the data, it was found that rats' total bilirubin ranged from $0.090-0.205 \mathrm{mg} / \mathrm{dl}$. This range is quite low compared to those in humans $\left(0.3\right.$ to $1.2 \mathrm{mg} / \mathrm{dl} .{ }^{13}$ It is necessary to perform baseline measurement prior to treatment to set a standard value of healthy rats.

In this study, rats were administered with toxic dose of AT, which is double the therapeutic dose, to induce hepatotoxicity in the rats. Figure 1 shows that the AT-treated rats experienced a significant increase in the serum total bilirubin. All animals (100\%) in the AT group had elevated total bilirubin above normal range, indicating a liver dysfunction in those rats. Elevated bilirubin total in serum may result from increased conjugated and/or unconjugated bilirubin. Unfortunately, this study did not measure the direct and indirect bilirubin to give a bit of information regarding the etiology of hyperbilirubinemia in these rats. It has been shown that isoniazid can damage hepatocyte due to increased stress oxidative, which attacking the cell membrane of hepatocytes, leading to increased serum ALT and AST. ${ }^{14}$ Meanwhile, mechanism of toxicity in rifampicin-treated rats involved a damage in bilirubin transporter, leading to cholestasis and increased bilirubin in serum. ${ }^{15}$

Following 28 days of treatments, it is shown that Paliasa leaf extract was able to hold further increased in total bilirubin. Although there was an increase in serum total bilirubin in Paliasa-treated rats, it was not significantly different from $\mathrm{NaCMC}$ group, indicating the elevation was not severe. In fact, with higher Paliasa extract dose $(500 \mathrm{mg} / \mathrm{kg})$ the total bilirubin was still in the range of normal baseline, indicating a hepatic protection by Paliasa extract in higher dose. It has been shown that Paliasa leaf contains antioxidant compounds that may beneficial to scavenge free radicals. ${ }^{16}$ The antioxidant compounds of Paliasa leaves have been found in its ethanolic extract, i.e cycloarthane terpenoid. ${ }^{17}$ It is suggested that Paliasa leaf also have a capacity to improve 
hepatotoxicity in animals induced by paracetamol, which mechanism may involve the increase in glutathione production in rat liver. ${ }^{18}$

\section{CONCLUSION}

Toxic dose of AT in rats induced liver injury that was characterized by a significant elevation of serum total bilirubin. The administration of Paliasa extract at the dose of $500 \mathrm{mg} / \mathrm{kg}$ prior to AT treatment in rats prevented the elevation of serum total bilirubin compared to those without Paliasa extract. The use of Paliasa leaf extract may find clinical significance to protect liver function from AT-induced liver damage.

\section{REFERENCES}

1. Alempijevic T, Zec S, and Milosavljevic T. Drug-induced liver injury: Do we know everything? World $J$ Hepatol 2017;9(10):491-502.

2. van Gulik TM. Assessment of liver function: What are we measuring? $H P B$ : the official journal of the International Hepato Pancreato Biliary Association 2013;15(5):325-326.

3. Rosenthal P. Assessing liver function and hyperbilirubinemia in the newborn. Clinical Chemistry 1997;43(1):228-234.

4. Yew WW and Leung CC. Antituberculosis drugs and hepatotoxicity. Respirology 2006;11(6):699-707.

5. Isa SE, Ebonyi AO, Shehu NY, Idoko P, Anejo-Okopi JA, Simji G, et al. Antituberculosis drugs and hepatotoxicity among hospitalized patients in jos, nigeria. International Journal of Mycobacteriology 2016;5(1):21-26.

6. Farazi A, Sofian M, Jabbariasl M, and Keshavarz S. Adverse reactions to antituberculosis drugs in iranian tuberculosis patients. Tuberculosis Research and Treatment 2014;2014:6.

7. e Castro AT, Mendes M, Freitas S, and Roxo PC. Incidence and risk factors of major toxicity associated to first-line antituberculosis drugs for latent and active tuberculosis during a period of 10 years. Rev Port Pneumol 2015;21(3):144150.
8. Gafar F, Arifin H, Jurnalis YD, Yani FF, Fitria N, Alffenaar J-WC, et al.

Antituberculosis drug-induced liver injury in children: Incidence and risk factors during the two-month intensive phase of therapy. The Pediatric Infectious Disease Journal 2019;38(1):50-53.

9. Tayeb R, Wahyudin E, Alam G, Pakki E, and Lukman L. Preclinical study: Hepatoprotective effects of "paliasa tea bag" on paracetamol-induced liver damage in rats. in The 2nd International on Naturopathic Medicine. 2014. Paris: ICNM.

10. Zhou C-X, Zou L, Gan L-S, and Cao YL. Kleinhospitines a-d, new cycloartane triterpenoid alkaloids from kleinhovia hospita. Org Lett 2013;15(11):27342737.

11. Raflizar R. Sub chronic toxicity test from alkohol extract paliasa leaves (kleinhovia hospita linn) to hepar/liver and kidney of experimental mice. Media Penelitian dan Pengembangan Kesehatan 2009;19(4 Des).

12. Djabir YY, Arsyad MA, Sartini S, and Lallo S. Potential roles of kleinhovia hospita 1. Leaf extract in reducing doxorubicin acute hepatic, cardiac and renal toxicities in rats. Pharmacognosy Research 2017;9(2):168-173.

13. Hull TD and Agarwal A. Bilirubin: A potential biomarker and therapeutic target for diabetic nephropathy. Diabetes 2014;63(8):2613-2616.

14. Attri S. Isoniazid- and rifampicin induced oxidative hepatic injury protection by n-acetylcysteine. Human Exp Toxicol 2000;19(9):517-522.

15. Kim J-H, Nam WS, Kim SJ, Kwon OK, Seung EJ, Jo JJ, et al. Mechanism investigation of rifampicin-induced liver injury using comparative toxicoproteomics in mice. International Journal of Molecular Sciences 2017;18(7):14-17.

16. Arung ET, Kusuma IW, Purwatiningsih $\mathrm{S}$, Roh S-S, Yang $\mathrm{CH}$, Jeon $\mathrm{S}$, et al. Antioxidant activity and cytotoxicity of the traditional indonesian medicine tahongai (kleinhovia hospita 1.) extract. $J$ Acupunct Meridian Stud 2009;2(4):306308. 
17. Gan L-S, Ren G, Mo J-X, Zhang X-Y, Yao W, and Zhou C-X. Cycloartane triterpenoids from kleinhovia hospita. $J$ Nat Prod 2009;72(6):1102-1105.
18. Tayeb R, Wahyudin E, Pakki E, Bahar A, and Alam G. Efek teratogenik dan mutagenik "tea bag" dan "kapsul paliasa" (kleinhovia hospita 1.) sebagai sediaan herbal terstandar hepatogeneratifhepatoprotektif. 2015. 